\title{
Consequences Of 2,4-D On Nitrate Reductase Activity And Nitrogen Content In Wheat And Its Relationship To Grain Protein
}

\author{
Neelam Sharma, Usha Rana And Swati Sharma \\ Department of Agronomy, Forages and Grassland management, CSK HPKV, Palampur \\ Effect of 2,4-D on nitrate reductase activity, nitrogen content in wheat and grain protein
}

\begin{abstract}
An investigation was carried out to study consequences of 2,4-D on nitrate reductase activity and nitrogen content in wheat and its relationship to grain protein in the Department of Agronomy, Forages and Grassland Management, CSK HPKV, Palampur. The field experiment consisting of four treatments viz. 2,4-D $0.5 \mathrm{Kg} \mathrm{ha}^{-1}(35 \mathrm{DAS}), 2,4-\mathrm{D} 1.0 \mathrm{Kg} \mathrm{ha}^{-1}$ (35 DAS), 2,4-D 2.0 Kg ha- (35 DAS) and control was laid out in randomized block design. A significant increase in nitrate reductase activity and nitrogen content in wheat was observed on application of 2,4-D $2.0 \mathrm{~kg} \mathrm{ha}^{-1}$ (35 DAS) at all the stages of development. Irrespective of treatments, in general, an increasing trend of nitrate reductase activity, nitrogen content and protein content in wheat was observed upto 30 days after herbicide application and thereafter declined upto 120 days after spray. Protein content in grain was positively correlated with nitrate reductase activity and nitrogen content in wheat leaves.
\end{abstract}

Keywords: 2,4-D, Nitrate Reductase activity, Nitrogen, Protein, Wheat

\section{Introduction}

Nitrogen is an important component of many structural, genetic and metabolic compounds in plant cells which is taken up by the plant in the form of nitrate. Nitrate is reduced to nitrite by substrate inducible enzyme nitrate reductase (NR). It is the rate limiting step in protein production (Beevers and Hageman 1969) and nitrogen assimilation in plants. 2,4-D (2,4-dichlorophenoxy) acetic acid is a systemic auxin type selective herbicide, belonging to phenoxy acetic group and is recommended to control broadleaf weeds in cereal crops. Some investigators have reported unacceptable injury in winter wheat on application of 2,4-D ( Soltani et al. 2006). Since the research in this area is very scanty, present study was undertaken to study the consequences of 2,4-D on nitrate reductase activity and nitrogen content in wheat and its relationship to grain protein.

\section{Materials And Methods}

Field investigations were conducted at the Research Farm and biochemical analysis was carried out in laboratory of Department of Agronomy, forages and grassland management CSK HPKV, Palampur. Wheat (variety HPW-155) seeds were sown with recommended packages and practices and 2,4-D was applied at $0.5 \mathrm{~kg}$ $\mathrm{ha}^{-1}, 1.0 \mathrm{~kg} \mathrm{ha}^{-1}$ and $2.0 \mathrm{~kg} \mathrm{ha}^{-1}$ in wheat crop at $35 \mathrm{DAS}$.The fresh plants from sampling rows were collected at different intervals of time i.e. 0, 30, 60, 90,120 days after herbicide spray. Nitrate reductase activity in fresh wheat leaves were estimated by method outlined by Nicholas and Nason (1957) and total protein content were estimated in oven dried samples $\left(60^{\circ} \mathrm{C}\right)$ by Micro Kjeldhals Method, A.O.A.C ( 1970). Grains were collected at maturity of crop and oven dried in hot air oven at $60^{\circ} \mathrm{C}$ to analyse protein content.

\section{Results And Discussion}

The data presented in Table 1 revealed the effect of different treatments of 2,4-D on nitrate reductase activity in wheat leaves and nitrogen content in wheat plant. In general, an increasing trend of NR activity and nitrogen content was exhibited upto 30 days and then a decline was noticed further upto 120 days. At zero day after herbicide application, the data on nitrate reductase activity in wheat leaves was not significant indicating that different treatments did not influence nitrate reductase activity significantly in wheat leaves. Among all the treatments at 30 days the maximum increase in nitrate reductase activity was observed in 2,4-D $2.0 \mathrm{~kg} \mathrm{ha}^{-1}$ (35 DAS) and the values varied from 0.52 to $0.61\left(\mu \mathrm{mol} \mathrm{NO}_{3}{ }^{-}\right.$reduced $\mathrm{g}^{-1}$ fresh weight hour $\left.{ }^{-1}\right)$. 2,4-D treatments i.e. $2.0 \mathrm{~kg} \mathrm{ha}^{-1} \quad$ (35 DAS) and $1.0 \mathrm{~kg} \mathrm{ha}^{-1}$ (35 DAS) resulted in significantly higher nitrate reductase activity in wheat over control check. However 2,4-D $0.5 \mathrm{~kg} \mathrm{ha}^{-1}$ (35 DAS) behaved statistically alike with control check. At 60 days after herbicide application, the maximum nitrate reductase activity in wheat leaves was observed in 2,4-D $2.0 \mathrm{~kg} \mathrm{ha}^{-1}$ (35 DAS) which behaved statistically alike with 2,4-D $1.0 \mathrm{~kg} \mathrm{ha}^{-1}$ (35 DAS). The nitrate reductase values varied from 0.40 to $0.44\left(\mu \mathrm{mol} \mathrm{NO}-\mathrm{N}_{3}\right.$ reduced $\mathrm{g}^{-1}$ fresh weight hour $\left.{ }^{-1}\right)$ with minimum and maximum values exhibited by control check and 2, 4-D $2.0 \mathrm{~kg} \mathrm{ha}^{-1}$ (35 DAS) treatments respectively. The trend 
of decrease in nitrate reductase activity in different treatments remained almost similar at 90 days after herbicide application. At 120 days after herbicide application, the data was found to be statistically non-significant.

At all the stages of observations except zero day, all 2,4-D applications increased nitrate reductase activity in leaves over control check which is indicative of effect of weed control by herbicide application. This might be attributed to reduced crop weed competition, absorption of mineral nutrients by wheat in particular $\mathrm{NO}_{3}^{-}$and $\mathrm{K}^{+}$ would have augmented and these two ions might have been responsible for inductive formation of nitrate reductase activity (Pandey and Srivastava 1985). The influence of 2,4-D on nitrate reduction may be a result of an alteration of nucleotide metabolism following herbicide application. Similar results of enhancement of nitrate reductase activity in corn leaves were reported by Beevers et al. (1963).

Data on effect of different treatments of 2,4-D on nitrogen content of wheat plant as shown Table 1 revealed that in all treatments, there was an increase in nitrogen content in wheat plant upto 30 days and considerable decline thereafter from 60 to 120 days after herbicide spray. Immediately after herbicide application corresponding to zero day, the data on total nitrogen content in wheat plant was non-significant indicating that different treatments did not influence total nitrogen content significantly. At 30 days after herbicide application, in all herbicide applied treatments total nitrogen content in wheat plant increased significantly over control check and maximum increase was recorded in 2,4-D $2.0 \mathrm{~kg} \mathrm{ha}^{-1}$ (35 DAS) treatment. The values of nitrogen content at 30 days after herbicide application varied from 50.7 to 62.5 ( $\mathrm{mg} \mathrm{g}^{-1}$ dry weight) with minimum and maximum value exhibited by control check and 2,4-D $2.0 \mathrm{~kg} \mathrm{ha}^{-1}$ (35 DAS). All 2,4$\mathrm{D}$ treatments resulted in significantly higher nitrogen content in wheat plant over control check at 60 days after herbicide application. The value of nitrogen content for whole plant varied from 27.5 to 31.0 ( $\mathrm{mg} \mathrm{g}^{-1}$ dry weight) with minimum and maximum value exhibited by control check and 2,4-D $2.0 \mathrm{~kg} \mathrm{ha}^{-1}$ (35 DAS) treatments, respectively. At 90 days after herbicide application significantly higher value (18.5 $\mathrm{mg} \mathrm{g}^{-1}$ dry weight) was reported in 2,4-D $2.0 \mathrm{~kg} \mathrm{ha}^{-1}$ (35 DAS) which behaved statistically at par with 2,4-D $1.0 \mathrm{~kg} \mathrm{ha}^{-1}$ (35 DAS) (17.7 $\mathrm{mg} \mathrm{g}^{-1}$ dry weight) followed by 2,4-D $0.5 \mathrm{~kg} \mathrm{ha}^{-1}$ (35 DAS) $\left(16.2 \mathrm{mg} \mathrm{g}^{-1}\right.$ dry weight), which was statistically at par with control check $\left(16.0 \mathrm{mg} \mathrm{g}^{-1}\right.$ dry weight). At 120 days after herbicide application the data on total nitrogen content was not significant. However, the trend of decrease in nitrogen content in wheat plant in different treatments remained almost similar with increase in number of days.

Dietary protein are of vital importance to living organisms as these perform vital biochemical functions in tissues as well as the body fluids including blood. Significantly highest value of protein content (12.4\%) was observed in 2,4-D $1.0 \mathrm{~kg} \mathrm{ha}^{-1}$ (35 DAS) treatment which was statistically at par with 2,4-D $2.0 \mathrm{~kg} \mathrm{ha}^{-1}$ (35 DAS) (12.3\%). The next best treatment was 2,4-D $0.5 \mathrm{~kg} \mathrm{ha}^{-1}$ (35 DAS) (11.5\%). Control check resulted in significantly lowest $(10.81 \%)$ protein content in grains.

The results of simple correlation studies between leaf NRA at 3060,90 and 120 days, leaf protein at 3060,90 and 120 days and grain protein had a positive significant correlation coefficients. The correlation coefficient values between leaf NRA at 30, 60, 90, and 120 days and grain protein were $0.802,0.811,0.928$ and 0.997 respectively. The correlation coefficient values between leaf protein at 30,60 and 90 days and grain protein were $0.947,0.949$, and 0.868 respectively.

The data on effect of 2,4-D on total nitrogen content ( $\mathrm{mg} \mathrm{g}^{-1}$ dry weight) of wheat indicated that 2,4-D treatments in general increased total nitrogen content of wheat plants as compared to control check. A similar trend was also observed in number of other investigations (Kent et al. 1957). Under better weed control situation, plants might have more potential for nutrients absorption because of reduced crop weed competition resulting in better growth of crops. This ultimately influenced the nitrate reductase activity. Nitrate is the major source for nitrogen in wheat plant and nitrate reductase is responsible for nitrogen assimilation. Therefore, a positive correlation between these characteristics in plant is quite plausible. As vegetative growth begins total nitrogen content in plant decreased with advancement of crop age and the decrease was maximum from 30 to 90 days after herbicide spray and this period corresponds to accumulation of protein in cereals grains. The correlation studies and the behaviour of nitrogen content in plant (Table 1) clearly supports this translocation of nitrogen from leaves to reproductive parts. The total protein content in wheat grain is also related to nitrate reductase activity as it contributes to the synthesis and mobilization of nitrogen to plants.

\section{References}

[1] A.O.A.C. (1970). Official Methods of the Association of Official Analytical Chemists. Washington DC, USA.

[2] Beevers, L., Peterson, D.M., Shannon, J.C. and Hageman, R.H. (1963). Comparative effects of 2,4-Dichlorophenoxy acetic acid on nitrate metabolism in corn and cucumber. Crop Physio.38: 675-679

[3] Beevers, L. and Hageman, R.H. (1969). Nitrate reduction in higher plants. Ann. Rev. Plant Physiol. 20: 495-522

[4] Kent ,N.L and Hutchinson, J.B. 1957. The effect of MCPA and 2,4-D herbicides on the quality of spring oats for milling and provender feeding. Ann. Appl. Biol. 45: 481-488

[5] Nicholas, D.J.D. and Nason, A. (1957). Determination of nitrate and nitrite. Methods of Enzymol.3: 981

[6] Pandey, M. and Srivastava, G.P. (1985). Nitrate reductase activity in wheat leaves as influenced by herbicide application and its relationship with grain protein content. Indian J. Agric. Chem.18: 239-245

[7] Soltani, N., Shropshire, C. and Sikkema, P.H. (2006). Responses of winter wheat (Tritium aestivum L.) to autumn applied post emergence herbicide.Crop Prot. 25: 346-349 